九州大学学術情報リポジトリ

Kyushu University Institutional Repository

\title{
STREPSIPTEROUS PARASITES OF HOMOPTERA INJURIOUS TO THE RICE PLANT IN SARAWAK, BORNE0, WITH DESCRIPTION OF A NEW SPECIES (Notulae Strepsipterologicae-III)
}

Hirashima, Yoshihiro

https://doi.org/10.5109/2372

出版情報: ESAKIA. 11，pp.53-58，1978-03-31. Entomological Laboratory，Faculty of Agriculture， Kyushu University

バージョン :

権利関係 : 


\title{
STREPSIPTEROUS PARASITES OF HOMOPTERA INJURIOUS TO THE RICE PLANT IN SARAWAK, BORNEO, WITH \\ DESCRIPTION OF A NEW SPECIES \\ $(\text { Notulae Strepsipterologicae-III })^{1)}$
}

\author{
Yoshiniro Hirashima \\ Entomological Laboratory. Faculty of Agriculture \\ Kyushu University, Fukuoka 812, Japan \\ and \\ TEI JI KIFUNE \\ Department of Parasitology, School of Medicine \\ Fukuoka University, Fukuoka 814, Japan
}

\begin{abstract}
Three species of the strepsipterons, Halictophagus munroei sp. n., Halictophagus spectrus Yang and Elenchus yasumatsui Kifune et Hirashima, which are parasitic on Homoptera injurious to the rice plant are recorded from Sarawak for the first time. Halictophagus helleri Kinzelbach is regarded as a synonom of Halictophagus spectrus Yang. In Sarawak, Halictophagus munroei is parasitic on Nephotettix nigropictus and Nephotettix virescens [Deltocephalidae], Halictophagus spectrus on Cicadella spectra [Cicadellidae] and Elenchus yasumatsui on Nilaparvata lugens [Delphacidae].
\end{abstract}

The material on which the present paper is based was collected by Dr. D. D. Munroe, Assistant Director of Agriculture, Agricultural Research Centre, Kuching, Sarawak, Malaysia, in the course of his study on the population dynamics of leafand plant hoppers in the paddy fields in Sarawak, and was sent to us for identification.

His material includes three species: Halictophagus munroei sp. n., Halictophagus spectrus which was described from China and recently recorded from Ceylon, and Elenchus yasumatsui which has been known from Thailand.

Colacina insidiator Westwood, 1877, which is the first strepsipteron recorded from Borneo, described on a single male cephalotheca found on Epora subtilis Walker [Tropiduchidae, Homoptera], was not found in the Munroe collection.

1) Contribution from the Entomological Laboratory, Faculty of Agriculture, Kyushu University, Fukuoka (Ser. 3, No. 44). 
HALICTOPHAGIDAE

1. Halictophagus munroei sp. $\mathrm{n}$.

Male. (Figs. 1-8, 10)

Size: Total length of body about 1.0-1.1 mm, length of head and thorax together about $0.68 \mathrm{~mm}$, wing expanse about $1.15 \mathrm{~mm}$, head breadth $0.38 \mathrm{~mm}$, metathoracic breadth $0.32 \mathrm{~mm}$, length of aedeagus $0.07 \mathrm{~mm}$.

Color: Body almost dark brown; antennae, pseudohalters (except axial portions being darker), legs, intersegmental membraneous parts of thorax, posterior marginal areas of scuta, anterior part of postscutellum, basisternum, pale brown; postlumbium almost decolored. Hind wings hyaline ; anterior and lateral marginal areas slightly darkened, veins brown, the area between SC and R dark brown, a small subtriangular portion just anterior to and near the middle of $\mathrm{M}$ distinctly darkened.

Structure : Typical form of the genus; head transversely elongate, frontal region anteriorly protruded, posterior portion deeply concave anteriorly as seen from above ; eyes hemispherical, with about 18 ommatidia as seen from above; antennae 7-segmented, 1 st and 2nd segments short, globular, subequal in length to each other, 3rd and 4th segments each with a long, flat and stout flabellum, each flabellum of 5th and 6th segments and 7th segment itself almost equal in size and shape to each other, and apparently smaller than flabella of two preceding segments; thus, the antennae being of unique form in contrast with other congeneric species. Mandibles elongate triangular ; maxillae 2-segmented, basal segment globular, distal segment clavate with a blunt tip.

Thorax narrower than head ; pro- and mesonota very short, acute as seen from above ; praescutum strongly convex, its anterior margin anteriorly curved ; slightly curved grooves visible between praescutum and both scuta ; scuta parallelogrammic, more or less convex; scutellum subpentagonal ; postlumbium with posterior margin posteriorly arcuate ; postscutellum with almost straight and posteriorly approaching two minute ridges on the dorsal side which is not so strongly convex.

Apical one-third of pseudohalters swollen, basal portion of them also slightly swollen, intermediate portion parallel-sided and slightly arcuate ; hindwing with $\mathrm{C}$, $\mathrm{Sc}, \mathrm{R}$, a fragmental vein posterior to $\mathrm{R}(=\mathrm{Rf})$, a fragmental $\mathrm{M}$ anterior to $\mathrm{M}(=\mathrm{Mf})$, $\mathrm{M}, \mathrm{Cu}, 1 \mathrm{~A}$, and $2 \mathrm{~A}$; Rf broad, with sharp exterior end ; Mf originating at about the median point of $\mathrm{M}$ and running obliquely to but not reaching wing margin at median point between $\mathrm{Rf}$ and $\mathrm{M}$; basal part of $\mathrm{M}$ received by a triangularly , expanded base of $\mathrm{R}$.

Legs normal :tarsi 3-segmented.

Figs. I-11. Halictophagus munroei sp. n. 1-10: male, 11: female. 1: Head and thorax, dorsal view. 2: Left antenna, frontal view. 3: Right hindwing, dorsal view. 4: Right mandible, frontal view. 5 : Right maxilla, frontal view. 6 : Right foreleg, dorsal view. 7: Right midleg, dorsal view. 8: Right hindleg, dorsal view. 9: Cephalotheca of puparium, frontal view. 10: Left aedeagus, lateral view. 11: Cephalothorax, ventral view (with enlarged ventral view of left mandible).-Figs. 1-9, 11: one scale, $0.1 \mathrm{~mm}$. Fig. 10: one scale, $0.05 \mathrm{~mm}$. Figs. 1 \& 2: with same scale. Figs. 4-9: with same scale. 


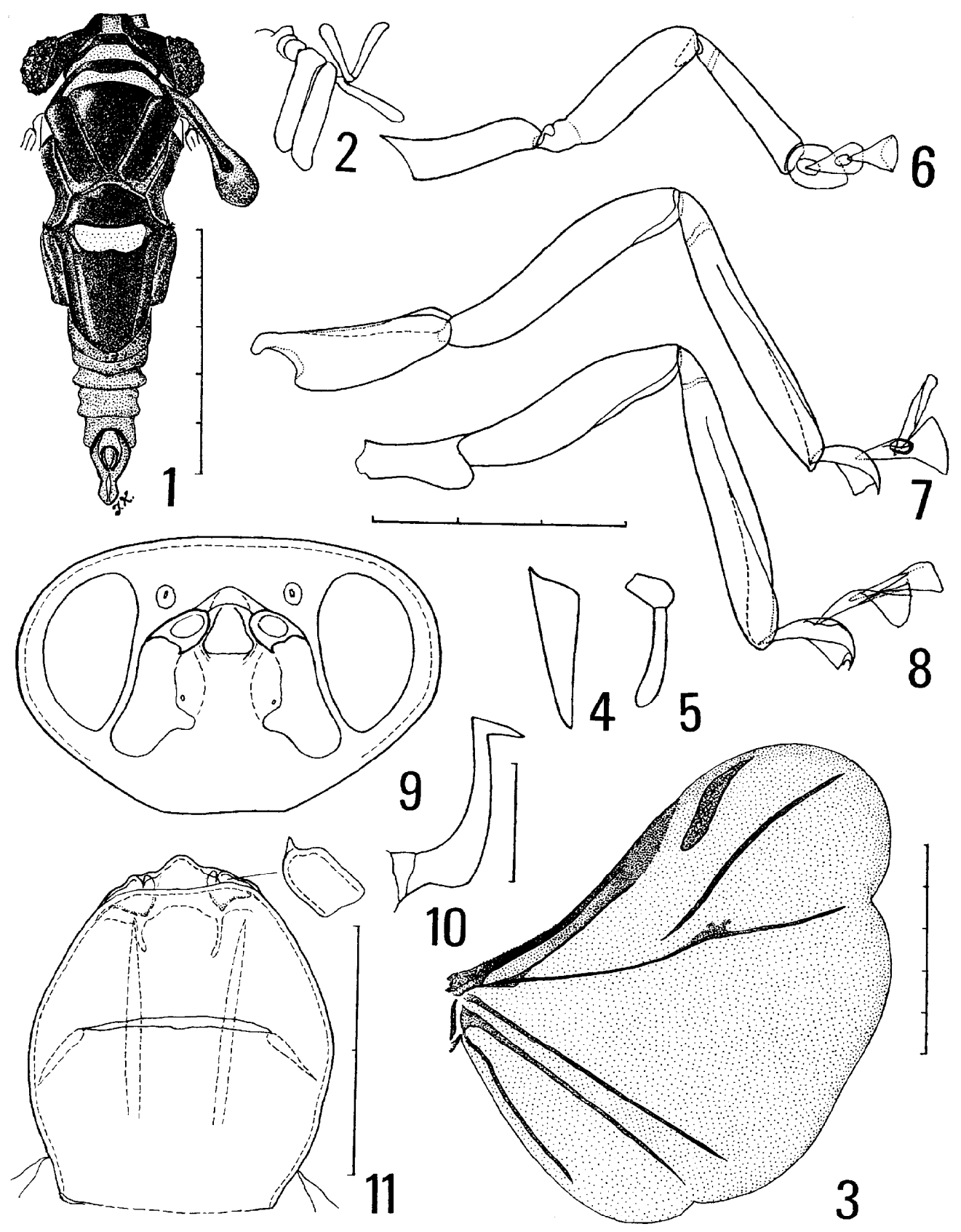


Abdomen slender and long, usually curved ventrally; abdominal segments narrow and short. Aedeagus with stem almost straight, hook rectangularly dorsally pointed with sharp tip.

Female. (Fig. 11)

Size: Body length about $0.70-0.71 \mathrm{~mm}$, breadth about $0.4-0.5 \mathrm{~mm}$ in young specimens ; cephalothorax 0.28-0.29 $\mathrm{mm}$ in length and $0.23-0.24 \mathrm{~mm}$ in breadth, distance between the cephalothoracic tip and anterior margin of opening of brood chamber $0.13 \mathrm{~mm}$, breadth of the opening $0.15-0.16 \mathrm{~mm}$.

Color: Body white in young specimens ; cephalothorax with anterior half beyond the opening of brood chamber brown, posterior portion dark brown; mandibles slightly darkened. Brood chamber also brown.

Structure : Cephalothorax situated at almost anterior tip of abdomen, subpentagonal, intermandibular area bluntly protruded ; dorsal side of cephalothorax with two inner long and two outer short longitudinal furrows which are darkened; opening of brood chamber with oblique furrows originating from both ends of it and directing posterolaterally ; spiracles just laterally situated.

M ale cephalotheca. (Fig. 9)

Size: Longitudinal length $0.30-0.32 \mathrm{~mm}$, transverse breadth $0.46-0.50 \mathrm{~mm}$.

Color: Brown, darker in sclerotized portions such as mandibular and marginal areas.

Structure: Conspicuously convex, transversely elongate and elliptical in shape. Median portion of ventral margin conspicuously arcuate outwardly and about onefourth of it straight in middle. Eyes and mouth parts as shown in figures.

Triungulin.

Unknown. No gravid female was obtained.

Type material (the type material was obtained from Nephotettix nigropictus (Stål) collected at Payah Paloh, Kuching, Sawarak by D. D. Munroe): Holotype male (Type No. 2086, Kyushu Univ.) from a female host, August 4, 1976; allotopotype female from a female host, August 18, 1976; 2 paratopotype males from 2 male hosts separately, 1 paratopotype male from 1 nymphal host, 3 paratopotype females from 3 female hosts separately, August 4, 1976; 1 paratopotype female from 1 male host, August 5, 1976; 1 paratopotype female from a male host, August 18, 1976. All of these are mounted by us.

Type depository : Holotype, allotopotype and 4 paratopotypes (2 males and 2 females) are deposited in the collection of the Entomological Laboratory, Faculty of Agriculture, Kyushu University, Fukuoka. Other paratopotypes (1 male and 3 females) are deposited in the collection of the Agricultural Research Centre, Kuching, Sarawak, Malaysia.

Specimens examined other than the type material: From Nephotettix nigropictus: 13 males from the males, females and nymphs of the host, July 22 to August 9, 1976 ; 2 male cephalothecae from 1 female host, August 4, 1976; 90 females from the males, females and nymphs of the host, July 22 to August 18, 1976. From Nephotettix virescens: 1 male, emerged on August 24, from 1 nymphal host collected on August 20, 1976; 1 female from 1 female host, August 20, 1976. A 11 
of the material, preserved in alcohol, was collected by D. D. Munroe, at the same locality with the holotype. These are put into the collections of the two institutions concerned.

Host: Nephotettix nigropictus (Stål) and Nephotettix virescens (Distant) [Hemiptera : Deltocephalidae].

Type locality : Payah Paloh, Kuching, Sarawak, Borneo.

Remarks : The present new species closely resembles, in general structure, Halictophagus bipunctatus Yang (1955), but differs from it in having slenderer terminal three flabella of the antennae and longer mandibles in the male and smaller teeth of mandibles in the female. This also resembles Halictophagus spectrus Yang (1965), recorded below, but differs from it by the smaller body.

\section{Halictophagus spectrus Yang, 1964}

Halictophagus spectrus. Acta Zootaxon. Sinica, 1 (1): 78 (81), figs. 7 \& 8, female. Host: Cicadella spectra (Distant). Type locality: Yaan, Szechuan, China.

Halictophagus helleri Kinzelbach, 1971, Stuttg. Beitr. Naturk. (230): 2, Abb. 2, male, female, male cephalotheca. Host: Cicadella spectra (Distant). Type locality: Kandy, Ceylon (=Sri Lanka). (New synonymy)

Kinzelbach thinks, by distributing a note in the mimeograph in 1972, that Halictophagus helleri Kinzelbach, 1971 from Ceylon is a synonym of Halictophagus spectrus Yang, 1964 from Szechuan, China. The present material which includes several male cephalothecae and female adults from Sarawak is well in accord with his description. Thus, Halictophagus helleri Kinzelbach is regarded here as a synonym of Halictophagus spectrus Yang.

Specimens examined : 2 male puparia in a female host, August 20, 1976, 2 females in 1 male and 1 female host separately, August 20, 1976, 1 female in 1 male host, August 23, 1976, 1 male cephalotheca from 1 female host, 6 females in 3 male and 3 female hosts separately, August 25, 1976. All of these are kept in alcohol except for 1 male cephalotheca from 1 female host, 1 female from 1 female host, August 25, 1976, which are mounted. These specimens are deposited in the collections of the two institutions concerned.

Host in Sarawak : Cicadella spectra (Distant> [Hemiptera : Cicadellidae].

Distribution : China (Szechuan), Ceylon and Borneo (Sarawak).

E L E N C H I D A E

3. Elenchus yasumatsui Kifune et Hirashima, 1975

Elenchus yasumatsui. Mushi, 48 (12): 146, pls. 1 \& 2, male, female, male cephalotheca. Host: Sogatella furcifera (Horváth) and $\mathbf{N}$ ilaparvata lugens (Stål). Type locality: Amphoe Hang Dons, Chiang Mai, Thailand.

This species was originally described from Thailand from the two species of plant hoppers injurious to the rice plant. The material from Sarawak is composed of a male adult and a male puparium, as stated below, taken from Nilaparvata lugens. 
Specimens examined: 1 male emerged on August 23 from 1 female host, August 20, 1976; 1 male puparium on 1 male host, same data as above. Both in alcohol. These are put in the collection of the Entomological Laboratory, Faculty of Agriculture, Kyushu University, Fukuoka.

Host in Sarawak : Nilaparvatalugens (Stål) [Hemiptera : Delphacidae].

Distribution: Thailand and Borneo (Sarawak).

\section{Acknowledgments}

We are much indebted to Dr. D. D. Munroe, Agricultural Research Centre, Kuching, Sarawak, Malaysia, for the valuable material and to Prof. T. Ishihara, Entomological Laboratory, Faculty of Agriculture, Ehime University, for the scientific names of the host.

\section{R eferences}

Kifune, T. and Y. Hirashima. 1975. A new species of the genus Elenchus from Thailand (Strepsiptera : Elenchidae) (Notulae Strepsipterologicae-II). Mushi, 48 (12) : 145-148, pls. $1-2$.

Kinzelbach, R. K. 1971. Morphologische Befunde an Fächerflüglern und ihre phylogene. tische Bedeutung (Insecta: Strepsiptera). Zoologica, (119): 1-256, 182 Abb.

1971a. Halictophagus helleri n. sp. von Ceylon (Insecta: Strepsiptera). Stuttg. Beitr.Naturk., (230): 1-8, 5 Abb.

Westwood, J. O. 1877. Notes upon a strepsipterous insect parasitic on an exotic species of Homoptera. Trans. ent. Soc. Lond., [1877]: 185-187, pl. 4.

Yang, C.-k. 1955. Description of a new species of Strepsiptera parasitic on the rice leafhoppers. Acta Ent. Sinica, 5: 327-333, pl. 1. (In Chinese with English description)

1964. Notes on the genus Halictophagus of China (Strepsiptera: Halictophagidae). Acta Zootaxon. Sinica, 1: 76-81, pl. 1. (In Chinese with English description) 